\title{
ANALYSIS OF POSTOPERATIVE OUTCOMES OF DEGENERATIVE DISEASES OF THE LUMBOSACRAL JUNCTION
}

\author{
ANÁLISE DOS RESULTADOS PÓS-OPERATÓRIOS DO DEGENERADOR DA \\ JUNÇÃO LOMBOSSACRAL

\section{ANÁLISIS DE LOS RESULTADOS POSTOPERATORIOS DE LAS ENFERMEDADES DEGENERATIVAS DE LA UNIÓN LUMBOSACRA}

\author{
Vadim Anatol'evich Byvaltsev $1,2,3,4$, Andrei Andreevich Kalinin ${ }^{1,2}$, Yuri Yakovlevich Pestryakov1, Samuil Semenovich Rabinovith ${ }^{5}$, \\ Marat Amangeldyevich Aliyev', Svetlana Victorovna Shvetsova ${ }^{6}$ \\ 1. Irkutsk State Medical University, Irkutsk, Russia. \\ 2. Railway Clinical Hospital, Irkutsk, Russia. \\ 3. Irkutsk Research Center Surgery and Traumatology, Irkutsk, Russia \\ 4. Irkutsk state medical academy of postgraduate education, Irkutsk, Russia. \\ 5. Novosibirsk scientific research Institute of traumatology and orthopedics named after Y. L. Tsivyan, Novosibirsk, Russia. \\ 6. Irkutsk state agrarian university named after A.A. Ezhevsky, Irkutsk, Russia.
}

\begin{abstract}
Objective: The article presents an analysis of the clinical efficacy and causes of unsatisfactory outcomes of surgical treatment in patients with degenerative diseases of the lumbosacral junction of the spine. Methods: Patients were allocated to one of three groups, depending on the method of surgical intervention on the lumbosacral junction: 1) $(n=352)$ - operated by the method of microsurgical discectomy; 2) $(n=83)$ - operated with the use of artificial IVD prostheses; 3) $(n=183)$ - operated with the use of interbody fusion and posterior rigid stabilization. To investigate the causes of unsatisfactory outcomes, a correlation analysis was conducted of long-term clinical outcomes with preoperative instrumental parameters in the operated segment, surgical tactics used, and the development of complications. Results: It is determined that long-term "good" clinical outcomes are associated with individual preoperative parameters of the lumbosacral junction of the spine - linear displacement, sagittal angulation, height of the interbody space, degree of IVD degeneration by ADC. Conclusion: In degenerative diseases of the lumbosacral junction of the spine, the detailed analysis of long-term clinical outcomes enable the identification of the causes that affect the development of unsatisfactory outcomes, which are individual morphostructural changes in the lower lumbar segment: the amplitude of the segmental angle, the angle of the lumbar lordosis, the degree of linear displacement of the vertebrae, the height of the interbody space, and ADC. Complex clinical and instrumental analysis enabled us to determine possible surgical tactics. Level of Evidence II; Prognostic Studies_-Investigating the Effect of a Patient Characteristic on the Disease Outcome.
\end{abstract}

Keywords: Intervertebral disc; Zygapophyseal joint; Chronic Disease; Discectomy; Spinal fusion; Arthroplasty.

\section{RESUMO}

Objetivo: O artigo apresenta a análise da eficácia clínica e as causas dos resultados insatisfatórios no tratamento cirúrgico de pacientes com doenças degenerativas da articulação lombossacral da coluna vertebral. Métodos: Dependendo do método da intervenção cirúrgica na junção lombossacral, três grupos de pacientes foram alocados: 1) (n=352) - operado pelo método de discectomia microcirúrgica; 2) ( $n=83$ ) - operado com a utilização de próteses artificiais IVD; 3) ( $n=183$ ) - operado com a utilização de fusão intercorporal e estabilização rígida posterior. Para investigar as causas de resultados insatisfatórios, foi realizada uma análise de correlação do desfecho clínico a longo prazo com parâmetros instrumentais pré-operatórios no segmento operado, táticas cirúrgicas e desenvolvimento de complicações. Resultados: Determinou-se que o resultado clínico "bom" a longo prazo está associado a parâmetros pré-operatórios individuais da junção lombossacral da coluna - deslocamento linear, angulação sagital, altura do espaço inter-corpo, grau de degeneração IVD por ADC. Conclusão: Nas doenças degenerativas da junção lombossacral da coluna vertebral, a análise detalhada do curso clínico a longo prazo, que é uma alteração morfoestrutural individual no segmento lombar inferior - a amplitude do ângulo segmentar, o ângulo de lordose lombar, o grau de deslocamento linear das vértebras, a altura do espaço de corpo intermédio, ADC, análise clínica e instrumental complexo - permitiu determinar possíveis táticas cirúrgicas. Nível de Evidência Il; Estudos prognósticos - Investigação do efeito de característica de um paciente sobre o desfecho da doença.

Descritores: Disco intervertebral; Articulação zigapofisária; Doença crônica; Discotomia; Fusão Vertebral Artroplastia.

\section{RESUMEN}

Objetivo: El artículo presenta el análisis de la eficacia clínica y causas de los resultados insatisfactorios de tratamiento quirúrgico de los pacientes con enfermedades degenerativas de la unión lumbosacra de la columna vertebral. Métodos: Dependiendo del método de la intervención quirúrgica sobre la unión lumbosacra, se asignaron tres grupos de pacientes: 1) (n = 352) - operado por el método de la discectomía microquirúrgica; 2) ( $n=83$ ) - operado con el uso de prótesis IVD artificiales; 3) ( $n=183)$ - operado con el uso de fusión intersomática y estabilización rígida posterior. Para investigar las causas de los resultados insatisfactorios, un análisis de correlación de 
los resultados clínicos a largo plazo con parámetros instrumentales preoperatorios en el segmento operado, tácticas y complicaciones quirúrgicas se llevó a cabo. Resultados: Se determina que a largo plazo "buenos" resultados clínicos están asociados con parámetros individuales preoperatorios de la unión lumbosacra de la columna vertebral - desplazamiento lineal, angulación sagital, altura del espacio intersomático, grado de degeneración IVD por ADC. Conclusión: En enfermedades degenerativas de la unión lumbosacra de la columna vertebral, el análisis detallado de los resultados clínicos a largo plazo hace posible la identificación de las causas que afectan al desarrollo de los resultados insatisfactorios, que son cambios individuales morfoestructurales en el segmento lumbar inferior - la amplitud del ángulo segmentario, el ángulo de la lordosis lumbar, el grado del desplazamiento lineal de las vértebras, la altura del espacio intersomático y ADC. El complejo análisis clínico e instrumental nos permitió determinar posibles tácticas quirúrgicas. Nivel de Evidencia II; Estudios pronósticos - Investigación del efecto de características de un paciente sobre el desenlace de la enfermedad.

Descriptores: Disco intervertebral; Articulación cigapofisaria; Enfermedad crónica; Discectomía; Fusión vertebral; Artroplastia.

\section{INTRODUCTION}

The dominant causes of the pain syndrome in the lumbar spine are associated with degeneration of the intervertebral discs (IVD), facet joints (FJ), or a combination of these facotrs. ${ }^{1,2}$ Different puncture, ${ }^{3,4}$ decompressive ${ }^{5,6}$ and decompressive-stabilizing surgical procedures $^{7,8}$ are used to treat different stages of the formation of degenerative disease of the vertebral segment.

The most important practice in spinal surgery is interventions in the transitional zones of the spine, in particular in the lumbosacral spine. ${ }^{9}$ In connection with biomechanical, anatomical and physiological features, this segment receives the greatest axial load and in the overwhelming majority of cases, is prone to degeneration. ${ }^{10}$ Complications of surgical interventions in patients with degenerative diseases of the lumbosacral junction of the spine are verified up to $57 \%$ of cases. ${ }^{11}$

The outcomes of decompressive and decompressive-stabilizing surgical interventions of various authors differ significantly; on one hand, this is due to a lack of objective criteria for their use, and on the other hand, to a large number of structurally different implants. ${ }^{12,13}$ This circumstance stimulates the development of approaches to predicting the degenerative process and determining the objective clinical and morphostructural parameters of the vertebral segment for performing personalized surgical tactics. ${ }^{14,15}$

Currently, the specialized literature presents little data on the clinical efficacy of various surgical techniques in isolated interventions in the lumbosacral spine.

The purpose of this study was to analyze the clinical efficacy and causes of unsatisfactory outcomes of surgical treatment of patients with degenerative diseases of the lumbosacral junction of the spine.

\section{METHODS}

The study was approved by the ethics committee of the Irkutsk State Medical University; each of the patients included in the study gave written informed consent - protocol No. 1 by January 13, 2010.

During the period from January 2007 to December 2012, 1342 decompressive and decompressive-stabilizing surgical interventions were performed in the lumbar spine at the Center for Neurosurgery of the "Railway Clinical Hospital" at the Irkutsk-Passenger Railway station of the Russian Railways. The study included 619 patients who underwent surgical interventions on the lumbosacral spine after a complex clinical and instrumental study. In all cases, the list of diagnostic procedures included the study of neurological and orthopedic status, spondylography, magnetic resonance imaging (MRI), multispiral computed tomography (MSCT), and electroneuromyography (ENMG) of the lower limbs.

The surgical interventions were performed in the presence of neurological signs of disco-radicular conflict and possible combination with reflex pain syndromes caused by hernias of the IVD, hypertrophy of the yellow ligament, and FJ arthrosis.

In 352 cases, microsurgical removal of the hernia of the IVD was performed by the Caspar method (group I), in 83 - discectomy through extraperitoneal pararectal access with implantation of the "M-6" disc prosthesis (Spinal Kinetics, USA) (group II), in 184 - unilateral facetectomy with or without contralateral foraminotomy, transforaminal spondylodesis using a "Capstone" cage (Medtronic, USA), and open transpedicular stabilization applying the "Conmet" system (Russia) through the median access; in a number of cases, reconstruction of the spinal canal was performed through the paramedian access in the volume of facetectomy with or without contralateral foraminotomy, and interbody fusion applying the "T-pal" cage (Synthesys, Switzerland) using the TLIF technique with combined transpedicular fixation. All patients were operated by the same surgical team, using original instrumentation.

After the operation, the follow-up catamnesis was a minimum of 24 months and a maximum of 48 months, with a median of 36 months. We studied anthropometric data (sex, age, body mass index), clinical parameters (the level of pain syndrome according to the visual analogue scale, patients' quality of life according to the Oswestry Disability Index (ODI) questionnaire, satisfaction with the results of the surgical treatment according to the Macnab scale), and instrumental parameters (for lumbar spondylography (height of interbody space, amplitude of segmental angle, angle of lumbar lordosis and degree of linear displacement of the vertebrae), according to MRI data (the degree of degenerative changes in IVD according to Pfirmann C. and FJ according to Fujiwara A., the quantitative characteristic of the degree of degeneration using the apparent diffusion coefficient (ADC)), and the presence of complications.

The data for ADC were obtained using a Siemens Magnetom Essenza MRI 1.5 T tomograph. The following set of parameters for the DW-MRI option with the SE-echo-planar image (EPI) was used: matrix $160 \times 128$, TR - 7500, TE - 83, NEX - 6, section thickness $4 \mathrm{~mm}$, FOV - $30 \times 30$. The following $b$ values were used: $b=400$ and $800 \mathrm{~cm} / \mathrm{mm} 2$, the scan time was 6 minutes and 30 seconds. The DC was calculated on a T2-WI using the OsiriX Lite program, and the resulting values were transferred to the functional DWI maps. The DC was calculated on a T2-WI using the OsiriX Lite program, and the values obtained were transferred to the functional DWI maps.

Statistical processing of the results of the research was carried out on a personal computer using Microsoft Excel and Statistica-8 data processing software. To assess the significance of differences in sample populations, the criteria of nonparametric statistics were used and $p<0.05$ was taken as the lower confidence limit. The data are represented by the median and interquartile range in the form of Me $(25 ; 75)$.

\section{RESULTS}

\section{General information about the studied patients}

General characteristics of the study groups by sex, age and constitutional characteristics are presented in Table 1. When studying the data, it was found that among the operated patients, males were prevalent in the young and middle aged groups (25-50 years).

In the retrospective analysis of neurological symptoms prior to the surgical treatment of degenerative diseases of the lumbosacral junction of the spine, it was established that in all study groups, the radicular symptomatology with various degrees of neurological deficit was verified.

A study of the presence of anomalies of the lumbosacral junction of the spine using instrumental data in patients of the study groups revealed their absence in a higher number of respondents in all groups of operated patients, respectively: $81.5 \%$, 95\% and $69 \%$.

The main types of pathomorphological substrate, according to the results of neuroimaging exams in degenerative diseases of the 
lumbosacral junction of the spine in the patients under study, are shown in Table 2. In the analysis, it was found that in most of the operated patients (>50\%) the combined pathology of the IVDs and FJs was verified.

\section{Analysis of clinical outcomes}

Characteristics of the parameters of the patients under study by the level of pain syndrome, the index of movement limitation in the lumbar spine, and the degree of patient satisfaction with the performed operation are shown in Table 3.

\section{Analysis of postoperative complications}

Complications, identified in the retrospective analysis, depending on the time of their verification and the type of surgical intervention, are shown in Table 4.

A detailed analysis of complications was carried out, based on the choice of the method of surgical treatment. In all study groups, due to strict adherence to the protocol for the prevention of vascular complications (elastic bandaging of the lower limbs, anticoagulant therapy), no venous thrombosis or pulmonary embolism were detected.

In all patients groups with surgical interventions on the lumbosacral spine, various complications typical for surgical intervention

Table 1. Distribution of patients by sex, age, and constitutional characteristics.

\begin{tabular}{c|c|c|c}
\hline Criteria & Group I (n= 352) & Group II (n= 83) & Group III (n= 184) \\
\hline age, yrs & $30(27 ; 48)$ & $29(26 ; 44)$ & $32(29 ; 49)$ \\
\hline Males $(\mathrm{n}, \%)$ & $214(61 \%)$ & $52(63 \%)$ & $119(65 \%)$ \\
\hline BMI $\left(\mathrm{kg} /{ }^{2}\right)$ & $24,2(22,3 ; 25,9)$ & $23,8(22,1 ; 26,2)$ & $24,9(23,3 ; 25,8)$ \\
\hline
\end{tabular}

Note: BMI - body weight index.

Table 2. Type of dominant degenerative morphostructural changes based on MRI results in patients of the study groups.

\begin{tabular}{|c|c|c|c|c|}
\hline $\begin{array}{c}\text { Type of } \\
\text { pathology }\end{array}$ & Morphological sign & $\begin{array}{c}\text { Group I } \\
(\mathrm{n}=352) \\
\end{array}$ & $\begin{array}{l}\text { Group II } \\
(n=83)\end{array}$ & $\begin{array}{l}\text { Group III } \\
(\mathrm{n}=184)\end{array}$ \\
\hline \multirow{4}{*}{$\begin{array}{c}\text { Degeneration } \\
\text { IVD }\end{array}$} & protrusion & $34(9,5 \%)$ & $49(59 \%)$ & $31(17 \%)$ \\
\hline & extrusion & $197(56 \%)$ & $25(30 \%)$ & $74(40 \%)$ \\
\hline & sequestration & $121(34 \%)$ & $9(11 \%)$ & $7(4 \%)$ \\
\hline & retrolisthesis & $76(22 \%)$ & $17(20 \%)$ & $11(6 \%)$ \\
\hline \multirow{3}{*}{$\begin{array}{c}\text { Degeneration } \\
\text { FJ }\end{array}$} & $\begin{array}{l}\text { spondylarthrosis } \\
\text { without spinal } \\
\text { stenosis }\end{array}$ & $162(46 \%)$ & 47 (57\%) & 35 (19\%) \\
\hline & \begin{tabular}{|c|} 
spondylarthrosis with \\
spinal stenosis
\end{tabular} & $24(7 \%)$ & - & $84(45 \%)$ \\
\hline & $\begin{array}{l}\text { spondylolisthesis } \\
\text { I degree }\end{array}$ & $4(1 \%)$ & $1(1 \%)$ & $29(16 \%)$ \\
\hline
\end{tabular}

Table 3. Distribution of the patients under study by clinical outcomes of surgical treatment.

\begin{tabular}{|c|c|c|c|c|}
\hline \multicolumn{2}{|c|}{ Criterion } & $\begin{array}{c}\text { Group I } \\
(n=352)\end{array}$ & $\begin{array}{l}\text { Group II } \\
(\mathrm{n}=83)\end{array}$ & $\begin{array}{l}\text { Group III } \\
(n=184)\end{array}$ \\
\hline \multicolumn{2}{|c|}{$\begin{array}{l}\text { VAS (lumbar spine) } \\
\text { before surgery, mm }\end{array}$} & $76(64 ; 80)$ & $76(64 ; 82)$ & $75(62 ; 82)$ \\
\hline \multicolumn{2}{|c|}{$\begin{array}{l}\text { VAS (lumbar spine) } \\
\text { in } 24 \text { months, mm }\end{array}$} & $18.5(11 ; 31)$ & $10.5(6 ; 14)$ & $22(16 ; 30)$ \\
\hline \multicolumn{2}{|c|}{$\begin{array}{l}\text { VAS (lower limbs) } \\
\text { before surgery, mm }\end{array}$} & $79(67 ; 83)$ & $79.5(66 ; 87)$ & $84(67 ; 89)$ \\
\hline \multicolumn{2}{|c|}{$\begin{array}{l}\text { VAS (lower limbs) } \\
\text { in } 24 \text { months, mm }\end{array}$} & $14.5(8 ; 26)$ & $8(4 ; 12)$ & $18(12 ; 25)$ \\
\hline \multicolumn{2}{|c|}{ ODI before surgery, score } & $76(66 ; 80)$ & $78(66 ; 82)$ & $74(60 ; 80)$ \\
\hline \multicolumn{2}{|c|}{ ODI in 24 months, score } & $18.5(14 ; 22)$ & $10(8 ; 14)$ & $17(14 ; 20)$ \\
\hline \multirow{4}{*}{$\begin{array}{c}\text { Macnab in } 24 \\
\text { months }\end{array}$} & Excellent, n, \% & $34(10)$ & $41(50)$ & $26(14)$ \\
\hline & Good, n, \% & $187(53)$ & $36(43)$ & $88(48)$ \\
\hline & Satisfactory, n, \% & $113(32)$ & $6(7)$ & $53(29)$ \\
\hline & Unsatisfactory, n, \% & $18(5)$ & - & $17(9)$ \\
\hline
\end{tabular}

Note: VAS - Visual Analogue Scale for pain. ODI - Functional state according to the Oswestry scale. Macnab - scale of subjective evaluation of treatment outcome.
Table. 4. Characteristics of the detected complications in the subgroups of the retrospective study.

\begin{tabular}{|c|c|c|c|}
\hline Criterion & $\begin{array}{c}\text { Group I } \\
(\mathrm{n}=352)\end{array}$ & $\begin{array}{l}\text { Group II } \\
(\mathrm{n}=83)\end{array}$ & $\begin{array}{l}\text { Group III } \\
(n=184)\end{array}$ \\
\hline Intraoperative, n, \% & $14(3.97 \%)$ & $3(3.6 \%)$ & $8(4.3 \%)$ \\
\hline Trauma DM & 3 & - & $3(1.63 \%)$ \\
\hline Damage to root & 4 & - & $3(1.63 \%)$ \\
\hline Tool breakage & 2 & - & $2(1.08 \%)$ \\
\hline Level error & 2 & - & - \\
\hline Conversion of method & 3 & - & - \\
\hline Damage to the main vessels & - & $3(3.6 \%)$ & - \\
\hline General Surgical, n, \% & $5(1.42 \%)$ & $4(4.81 \%)$ & $9(4.89 \%)$ \\
\hline $\begin{array}{c}\text { Formation of postoperative } \\
\text { hematoma }\end{array}$ & 3 & 1 & 5 \\
\hline Infection of a postoperative wound & 2 & 3 & 4 \\
\hline Venous thrombosis, PE & - & - & - \\
\hline Specific, n, \% & $52(14.77 \%)$ & $3(3.6 \%)$ & $25(13.6 \%)$ \\
\hline Spondylodisitis & \begin{tabular}{|c|}
1 \\
\end{tabular} & \begin{tabular}{|l|}
- \\
\end{tabular} & - \\
\hline $\begin{array}{c}\text { Deterioration of neurologic } \\
\text { symptoms }\end{array}$ & 15 & 1 & 8 \\
\hline Recurrent hernia IVD & 12 & - & - \\
\hline $\begin{array}{c}\text { Formation of a herniated disc } \\
\text { adjacent segment }\end{array}$ & 3 & - & 9 \\
\hline Segmental instability & 21 & - & - \\
\hline Pseudoarthrosis & - & - & 7 \\
\hline Instability of the fixing structure & - & - & 1 \\
\hline Heterotopic ossification & - & 2 & - \\
\hline
\end{tabular}

Note: DM - dura mater; PE - pulmonary embolism.

and method of access were revealed. Thus, in the group of patients operated on by the method of microsurgical removal of herniated IVD, long-term adverse effects in the form of recurrent hernias of IVD and development of segmental instability were prevalent. In the group of patients operated on by the method of dynamic fixation, the lowest level of postoperative complications was revealed; mainly damage to the main vessels during access, infection of the postoperative wound, and the phenomena of heterotopic ossification. In the group of patients operated on by the method of rigid stabilization, complications related to degeneration of the adjacent segment, development of pseudoarthrosis, and instability of the fixation structure were determined.

\section{Analysis of clinical-biomechanical parameters of the affected vertebral-motor segments of patients, and their relationship with the outcome of surgical treatment}

The leading clinical characteristics that have a direct relationship with the clinical postoperative outcome and the level of quality of life were the degree of pain syndrome according to VAS, and functional state (ODI). A correlation analysis of the above clinical components and parameters was performed, characterizing the state of the lumbosacral junction of the spine: amplitude of the segmental angle, angle of the lumbar lordosis, degree of linear displacement of the vertebrae, height of the interbody space, and ADC. A significant positive nonparametric correlation was revealed between the values for long-term outcomes of surgical treatment by VAS and ODI with the parameters studied $(R>0.5, p<0.05)$

In order to conduct a detailed analysis of the effect of the clinical and instrumental parameters on the clinical outcome, and study the possibility of optimizing the tactics of treating patients with degenerative diseases of the lumbosacral junction of the spine, the results of the study were divided by postoperative outcomes, as follows: - "good", characterized by a complete or near-complete return to the previous levels (before the onset of the disease or before the last exacerbation) of social and physical activity (possible limitation of large physical exertion);

- "unsatisfactory", household and social activity is not fully restored, no effect after the surgery or deterioration of the state.

A comparison of the clinical and instrumental data of patients in the study groups is shown in Table 5 . 
Table 5. Comparative analysis of clinical data depending on the postoperative outcome of the study patients groups.

\begin{tabular}{|c|c|c|c|c|c|c|}
\hline Criterion & \multicolumn{2}{|c|}{ Group I ( $n=352)$} & \multicolumn{2}{|c|}{ Group II $(n=83)$} & \multicolumn{2}{|c|}{ Group III $(n=184)$} \\
\hline ODI 36 months & $12(10 ; 16)$ & $26(20 ; 28)^{*}$ & $8(6 ; 10)$ & $12(10 ; 14)^{*}$ & $14(12 ; 18)$ & $30(24 ; 36)^{*}$ \\
\hline VAS lower limbs 36 months & $6.5(4 ; 9)$ & $25.5(18 ; 35)^{*}$ & $2(2 ; 4)$ & $10(6 ; 16)^{*}$ & $10(6 ; 12)$ & $28(20 ; 36)^{*}$ \\
\hline LT before surgery & $2(1 ; 2)$ & $4(3 ; 6)^{*}$ & $2(1 ; 4)$ & $6(5 ; 7)^{*}$ & $7(4 ; 11)$ & $3(2 ; 3)^{*}$ \\
\hline LT after surgery & $2(1 ; 3)$ & $7(6 ; 8)^{*}$ & $1(1 ; 2)$ & $2(1 ; 2)$ & $2(1 ; 3)$ & $5(4 ; 7)^{*}$ \\
\hline General lordosis before surgery & $32(28 ; 34)$ & $30(26 ; 32)$ & $30(28 ; 36)$ & $30(26 ; 38)$ & $32(28 ; 36)$ & $32(23 ; 38)$ \\
\hline General lordosis after surgery & $34(26 ; 36)$ & $28(24 ; 34)$ & $54(48 ; 64)$ & $34(32 ; 36)^{*}$ & $52(44 ; 66)$ & $37(32 ; 38)^{*}$ \\
\hline Disc height before surgery & $12(11 ; 14)$ & $8(7 ; 10)^{*}$ & $10(9 ; 13)$ & $6(5 ; 9)^{*}$ & $6(5 ; 8)$ & $10(9 ; 12)^{*}$ \\
\hline Disc height after surgery & $10(10 ; 12)$ & $6(5 ; 7)^{*}$ & $12(10 ; 12)$ & $10(10 ; 12)$ & $12(10 ; 14)$ & $11(10 ; 13)$ \\
\hline$A D C$ & $1720(1600 ; 1830)$ & $1300(1190 ; 1480)^{*}$ & $1540(1280 ; 1760)$ & $1050(800 ; 1150)^{*}$ & $1180(980 ; 1230)$ & $1320(1240 ; 1520)^{*}$ \\
\hline
\end{tabular}

Note: LD - linear translation; SA - sagittal angulation; ADC - apparent coefficient diffusion; ${ }^{*}$ - the reliability of differences between the groups studied at the same stages of the study.

\section{The analysis found that}

In the group of patients operated on using the technique of microsurgical removal of the hernia of IVD, "good" outcomes are associated with the following preoperative parameters of the lumbosacral junction of the spine: LT - no more than $2 \mathrm{~mm}$., sagittal volume of movements - no more than $6^{\circ}$, lowering the height of the interbody space no more than $1 / 3$ of the overlying, I and II degree of IVD degeneration by ADC.

In the group of patients operated on using the technique of dynamic fixation, "good" outcomes are associated with the following preoperative parameters of the lumbosacral junction of the spine: LD - no more than $4 \mathrm{~mm}$., sagittal volume of movements - no more than $6^{\circ}$, lowering the height of the interbody space no more than $2 / 3$ of the overlying, II and IV degree of IVD degeneration by ADC.

In the group of patients operated on using the technique of rigid stabilization, "good" outcomes are associated with the following preoperative parameters of the lumbosacral junction of the spine: LT - more than $4 \mathrm{~mm}$., sagittal volume of movements - more than $6^{0}$, lowering the height of the interbody space more than $2 / 3$ of the overlying, IV and V degree of IVD degeneration by ADC

\section{DISCUSSION}

The different degrees of degenerative changes in the lumbar segments is an indication for the use of a variety of surgical technologies. ${ }^{3}$ In each clinical situation, it is necessary to determine the optimal indications for performing an operative intervention. The promotion of minimally invasive methods for treating degenerative diseases led to the widespread introduction of microsurgical (subtotal) discectomy. The long-term outcomes of using the above-mentioned method testify to its lack of clinical effectiveness. ${ }^{16,17}$

Currently, the most common method of surgical treatment of degenerative diseases of the lumbar spine is interbody fusion and rigid stabilization, whereby successful clinical outcomes do not correlate with radiographic outcomes. ${ }^{2,7}$ Rigid stabilization leads to biomechanical stress of adjacent segments with their accelerated degeneration, contributing to the formation of bone block failure, development of infectious complications, postoperative pain syndrome, instability of fixation elements, and resorption of bone tissue around the implants. ${ }^{1,2,18}$

The study of technical capabilities aimed at reducing the unsatisfactory outcomes of rigid stabilization is associated with protection of adjacent segments from biomechanical overload, a reduction in the risk of breakage of the fixing structure, and elimination of pathological mobility, with preservation of the physiological volume of movements in the operated segment. ${ }^{2,19}$ It is determined that the posterior dynamic stabilization allows the physiological volume of movements in the lumbar spine to be restored, and reduces the degeneration of the adjacent segment. ${ }^{12,20}$ In modern specialized literature there are data on positive clinical postoperative outcomes, but the biomechanical effects of using various stabilizing structures are contradictory. ${ }^{12,18}$

Dynamic fixation using artificial IVD is aimed at restoring spatial relationships and biomechanics in the operated segments of the spine, if there are no significant morphostructural changes in its support elements. In connection with this, a detailed preoperative examination of patients is necessary, taking into account modern neuroimaging methods of examination. ${ }^{21,22}$

When analyzing the specialized literature, we did not observe any fundamental differences in the clinical outcomes of VAS and ODI in each of the surgical correction groups. ${ }^{3,7,8}$ At the same time, in this study, lower indicators for the level of pain in the lumbar and lower limbs and quality of life by ODI were determined in a group of patients operated with the application of artificial IVD M-6.

The study confirmed the presence of the most common complications after microsurgical discectomy - recurrence of hernias of the IVD and segmental instability; 6,17 after total arthroplasty - damage to the main vessels and heterotopic ossification, ${ }^{23,24}$ after rigid stabilization - degeneration of adjacent segments, pseudoarthrosis, and postoperative scar process. ${ }^{7,8}$

Determination of prognostic factors and the relationship of long-term postoperative outcomes with clinical and instrumental preoperative changes in the area of planned surgical intervention is currently relevant.

The complex study of various morphostructural factors determined by instrumental data, and which influence the long-term clinical outcome, make it possible to manage and monitor the long-term postoperative outcome in patients with degenerative diseases of the lumbosacral junction of the spine.

\section{CONCLUSION}

Lesions of the lumbosacral spine constitute a complex group of degenerative diseases, and determining the best surgical conduct requires a comprehensive clinical and instrumental analysis.

In spite of the overall clinical effectiveness of surgical interventions, the detailing of long-term outcomes enabled us to identify the causes that influence the development of unsatisfactory outcomes; which are the individual morphostructural features of the lower lumbar VMS - the amplitude of the segmental angle, the lumbar lordosis angle, the degree of linear displacement of the vertebrae, the height of the interbody space, and the ADC.

The development of a detailed algorithm of tactics and a multicenter study of its implementation, are current trends in spinal surgery that will improve the outcomes of surgical treatment of patients with degenerative diseases of the lumbosacral junction of the spine.

All authors declare no potential conflict of interest related to this article. 
CONTRIBUTION OF THE AUTHORS: Each author made significant individual contributions to this manuscript. VAB (0000-0003-4349-7101)* and SSR (0000-0002-2796-5692)* were the main contributors in the drafting of the manuscript. AAK (0000-0001-9039-9147)* and YYP $(0000-0003-2633-$ 7149) performed the surgery, followed up the patients and gathered clinical data. MAA (0000-0002-7676-1127)* evaluated the data from the statistical analysis. SVS (0000-0002-6634-1727)*, AAK and VAB performed the literature search and review of the manuscript, and contributed to the intellectual concept of the study. ${ }^{\star}$ ORCID (Open Researcher and Contributor ID).

\section{REFERENCES}

1. Kalinin AA, Byvaltsev VA. Relationship between vertebral metric parameters and outcome of surgical treatment of degenerative spondylolisthesis with multilevel lumbar intervertebral disc lesions. Spine surgery. 2015;4:56-62. [In Russian].

2. Krutko AV. Comparative analysis of the results of posterior interbody fusion (PLIF) and transforaminal interbody fusion (TLIF) in combination with transpedicular fixation. Herald of traumatology and orthopedist. them. N.N. Priorov. 2012;1:12-21. [In Russian]

3. Feng $\mathrm{F}, \mathrm{Xu}$ Q, Yan F, Xie Y, Deng Z, Hu C et al. Comparison of 7 Surgical Interventions for Lumbar Disc Herniation: A Network Meta-analysis. Pain Physician. 2017;20(6):E863-71.

4. Song $\mathrm{H}, \mathrm{Hu}$ W, Liu Z, Hao Y, Zhang $X$. Percutaneous endoscopic interlaminar discectomy of L5-S1 disc herniation: a comparison between intermittent endoscopy technique and full endoscopy technique. J Orthop Surg Res. 2017;12(1):162.

5. Faldini C, Perna F, Chehrassan M, Borghi R, Stefanini N, Traina F. Surgical tricks for open lumbar discectomy. Eur Spine J. 2017;26(Suppl 3):425-6.

6. Teli M, Lovi A, Brayda-Bruno M, Zagra A, Corriero A, Giudici F et al. Higher risk of dural tears and recurrent herniation with lumbar micro-endoscopic discectomy. Eur Spine J. 2010:19(3):443-50.

7. Byvaltsev VA, Kalinin AA, Belykh EG, Sorokovikov VA, Shepelev VV. Optimization of segmental lumbar spine instability treatment using minimally invasive spinal fusion technique. Questions of neurosurgery. 2015;3:45-54. [In Russian]

8. Hoff EK, Strube P, Pumberger M, Zahn RK, Putzier M. ALIF and total disc replacement versus 2-level circumferential fusion with TLIF: a prospective, randomized, clinical and radiological trial. Eur Spine J. 2016;25(5):1558-66.

9. Kolesov SV, Kolbovsky DA, Kazmin Al, Morozova NS. Application of nitinol rods in surgical treatment of dehenerative spine diseases with fixation of the lumb-cross transition. Spine surg. 2016;13(1):41-9. [In Russian]

10. Bydon M, Xu R, Santiago-Dieppa D, Macki M, Sciubba DM, Wolinsky JP et al. Adjacent-segment disease in 511 cases of posterolateral instrumented lumbar arthrodesis: floating fusion versus distal construct including the sacrum. J Neurosurg Spine. 2014;20(4):380-6.

11. Hashem S, Abdelbar A, Ibrahim H, Alaa-Eldin Habib M, Abdel-Monem A, Hamdy H. Review of device and operator related complications of transpedicular screw fixation for the thoracic and lumbar regions. Egypt J Neurol Psychiat Neurosurg. 2012;49(4):393-8.

12. Kaner T, Sasani M, Oktenoglu T, Cosar M, Ozer AF. Utilizing dynamic rods with dynamic screws in the surgical treatment of chronic instability: a prospective clinical study. Turk Neurosurg. 2009;19(4):319-26.
13. Sköld C, Tropp H, Berg S. Five-year follow-up of total disc replacement compared to fusion: a randomized controlled trial. Eur Spine J. 2013;22(10):2288-95.

14. Konovalov NA, Shevelev IN, Kornienko VN, Nazarenko AG. Clinical and diagnostic evaluation of the severity of degenerative lesion of the lumbosacral spine. Annals of clinical and experimental neurology. 2009;3(3):16-21. [In Russian]

15. Belykh E, Krutko AV, Baykov ES, Giers MB, Preul MC, ByvaltsevVA. Preoperative estimation of disc herniation recurrence after microdiscectomy: predictive value of a multivariate model based on radiographic parameters. Spine J. 2017;17(3):390-400.

16. Caspar W, Campbell B, Barbier DD, Kretschmmer R, Gotfried Y. The Caspar microsurgical discectomy and comparison with a conventional standard lumbar disc procedure. Neurosurgery. $1991 ; 28(1): 78-86$.

17. Castro-Menéndez M, Bravo-Ricoy JA, Casal-Moro R, Hernández-Blanco M, Jorge-Barreiro FJ. Midterm outcome after microendoscopic decompressive laminotomy for lumbar spinal stenosis: 4-year prospective study. Neurosurgery. 2009;65(1):100-10.

18. Ozer F, Yaldiz C, Ozkal B, Guvenc Y, Senturk S, Erbulut D et al. Comparison of the Rigid Rod System with Modular Plate with the Finite Element Analysis in ShortSegment Posterior Stabilization in the Lower Lumbar Region. Turk Neurosurg. 2017;27(4):610-6

19. Imada AO, Huynh TR, Drazin D. Minimally Invasive Versus Open Laminectomy/ Discectomy, Transforaminal Lumbar, and Posterior Lumbar Interbody Fusions: A Systematic Review. Cureus. 2017:9(7):e1488.

20. Bothmann M, Kast E, Boldt GJ, Oberle J. Dynesys fixation for lumbar spine degeneration. Neurosurg Rev. 2008;31(2):189-96.

21. Belykh EG, Kalinin AA, Patel AA, Miller EJ, Bohl MA, Stepanov IA et al. Apparent diffusion coefficient maps in the assessment of surgical patients with lumbar spine degeneration. PLoS ONE. 2017;12(8): e0183697.

22. Yu HJ, Bahri S, Gardner V, Muftuler LT. In vivo quantification of lumbar disc degeneration: assessment of $A D C$ value using a degenerative scoring system based on Pfirrmann framework. Eur Spine J. 2015;24(11):2442-8.

23. Kim J, Kim Y, Jeong WK Song SY, Cho OK. Heterotopic ossification developing in surgical incisions of the abdomen: analysis of its incidence and possible factors associated with its development. J Comput Assist Tomogr. 2008;32(6):872-6.

24. Le Huec JC, Mathews $\mathrm{H}$, Basso Y, Aunoble S, Hoste D. Clinical results of Maverick lumbar total disc replacement: two-year prospective follow-up. Orthop Clin North Am. 2005;3(6):315-22 